\title{
Task-based Teaching by English Majors in the Learning of English Culture
}

\author{
Guanghua Li \\ Institute of Foreign Languages, Shandong University of Technology, Zibo, Shandong, 255000, China
}

Keywords: Task-based Teaching by English Majors, English Culture, Language Skill, Cultural Content, Learning Ability

Abstract: To help the English majors build up their English cultural knowledge, improve their English proficiency and develop their learning ability, the current study has tried some operable and assessable instructional activities in the course of A survey of Englishspeaking Countries. Of all the activities, the practice of task-based teaching by English majors proves the most effective. The paper, after making a tentative study of the practice in task designing, implementation, assessment and workability, found it effective and workable.

\section{Introduction}

A Survey of English-speaking countries (hereinafter referred to as the Survey), a compulsory course for English majors to study English culture at initial stage, aims to help the English majors build up English cultural knowledge, cultivate cross-cultural awareness, improve English proficiency and eventually communicate successfully with people from English-speaking countries.

Over years of teaching practice, the author has observed some disturbing instructional practices, e.g. emphasizing the accumulation of cultural knowledge while overlooking the growth of English competence; giving priority to teacher-centered approaches over student-centered methods. Enlightened by content-based instruction(CBI) and constructivism teaching theories, the author has designed and carried out some instructional activities in the hope of addressing the abovementioned problems and helping students make the most out of the Survey.

Task-based teaching by English majors is, in essence, a task-based assignment, which requires students to employ English in the course of collecting and processing information, making PPTs, collaborating with peers, lecturing in front of the whole class and commenting on peer performances. Students, assessment-driven, are forced to construct their English cultural knowledge, meanwhile harvesting their English competence as a side product.

\section{Theoretical foundations}

CBI is an approach to curriculum development, with focus on balancing language and content instruction... that is, to teach language through content in order to achieve integration of 
meaningful cultural content into the FL curriculum. ${ }^{[1]}$

CBI can be traced back to the Canadian experiment with French immersion schooling in St. Lambert, Quebec in $1965^{[2]}$, and soon internationally acclaimed, and credited as one of the main ingredients that explain the success of language immersion education ${ }^{[3]}$.

Experimentation with the implementation of content-based curricula at home and abroad provides clear evidence of its effectiveness. And research, though a recent phenomenon, has also shown CBI to be effective in foreign language educational contexts ${ }^{[1]}$.

Chang Junyue and his colleagues' systemic experiments with CBI among English majors at initial stage at Dalian University of Foreign Languages prove very successful ${ }^{[4][5]}$

Constructivism learning theory advocates that learners construct knowledge out of their experiences. In the learning process, teachers should act as little as possible, whereas learners should be actively involved.

Constructivism learning theory also advocates learning by teaching. A good content teacher is often also a facilitative teacher of second language learners. (Teachers should) construct environments in which second language learners can learn through "theme-based language instruction"-topic-led version of communicative language teaching. ${ }^{[6]}$ By experiencing the successful completion of interesting, challenging, demanding, and rewarding tasks, learners gain confidence and motivation to embark on more complex challenges.

Constructivism learning theory views assessment as a two-way process involving interaction between both teachers and students. The feedback created by the assessment process serves as a direct foundation for further learning.

\section{Implementation of Task-based Teaching by English Majors}

The Survey is a 32-credit compulsory course for freshman English majors of Institute of Foreign Languages, Shandong University of Technology, which lasts 16 weeks, with each week focusing on one cultural topic, therefore, is an ideal course to achieve the convergence of cultural content and language skill.

To practice the cultural theme-based language instruction in the Survey, teachers carefully design some practicable and measurable before-, in- and after-class assignments. At each class meeting, teachers scaffold the cultural topic, leaving details to be built up by students themselves. One of the assignments is task-based teaching by student which will be elaborated in the paragraphs to follow.

The author invites some fellow teachers and students to work out a list of tasks (table 1) in line with the cultural topics, meanwhile, rubrics are co-designed. At the first class meeting, both the task list and the rubrics are demonstrated to students, who are free to pick up tasks of their interests and then choose their partners. Chances are some tasks might be quickly signed up, whereas others might be sadly deserted. In this case, the author will step in to make sure that all tasks are claimed. 
Table 1 List of cultural topics and teaching tasks

\begin{tabular}{|c|c|c|}
\hline week & topics & tasks \\
\hline 1 & Orientation & Please share some cultural shocks you have experienced. And explain the causes behind. \\
\hline 2 & $\begin{array}{l}\text { A brief of the } \\
\text { UK }\end{array}$ & $\begin{array}{l}\text { Suppose you are a tourist guide and ready to receive } 5 \text { FIT( free itinerary travel) foreign } \\
\text { visitors for a day tour in London. Work out an itinerary and a brief of the scenic spots to } \\
\text { be visited for them. }\end{array}$ \\
\hline 3 & $\begin{array}{l}\text { Political } \\
\text { System of the } \\
\text { UK }\end{array}$ & $\begin{array}{l}\text { General election is a big issue in the everyday life in the U.K, Try to explain it by } \\
\text { examining the } 2017 \text { General Election. }\end{array}$ \\
\hline 4 & $\begin{array}{l}\text { Religion in the } \\
\text { UK }\end{array}$ & $\begin{array}{l}\text { Western culture is largely Christian culture. Brief the original sin, birth and resurrection } \\
\text { of Jesus Christ. }\end{array}$ \\
\hline 5 & $\begin{array}{l}\text { Education } \\
\text { System of the } \\
\text { UK }\end{array}$ & $\begin{array}{l}\text { Suppose you have the chance to study in the U.K. after high school. Which university } \\
\text { would you like to choose? Please provide facts and figures in terms of its geographical, } \\
\text { historical or academic advantage etc. }\end{array}$ \\
\hline 6 & $\begin{array}{l}\text { Holidays in } \\
\text { Britain }\end{array}$ & $\begin{array}{l}\text { Give a brief introduction to holidays in the } 4 \text { nations: Guy Fawkes Night, St. Patrick's } \\
\text { Day, Hogmanay, and Eisteddfod. }\end{array}$ \\
\hline 7 & $\begin{array}{l}\text { A Brief of } \\
\text { Ireland }\end{array}$ & $\begin{array}{l}\text { Please introduce Irish folk dance - tap dance with music and video clips. You can use } \\
\text { River dance as a case study for the features and development of tap dance. }\end{array}$ \\
\hline 8 & $\begin{array}{l}\text { A Brief of } \\
\text { Australia }\end{array}$ & $\begin{array}{l}\text { Australia is an ancient land of unique flora and fauna. Why is it so? Watch the video } \\
\text { Australia's singular journey, and then introduce some typical animals and plants there. }\end{array}$ \\
\hline 9 & $\begin{array}{l}\text { A brief of } \\
\text { New Zealand }\end{array}$ & ays, one of which is Maoritanga. Try to \\
\hline 10 & $\begin{array}{l}\text { Geography of } \\
\text { the U.SA }\end{array}$ & Please find at least 2 symbols of the USA, and elaborate on them. \\
\hline 11 & $\begin{array}{l}\text { American } \\
\text { Beginnings }\end{array}$ & $\begin{array}{l}\text { Watch the Disney movie The Colour of Wind, and then make a brief introduction to the } \\
\text { establishment of the British settlement in Virginia. }\end{array}$ \\
\hline 12 & $\begin{array}{l}\text { Government of } \\
\text { the U.S.A }\end{array}$ & $\begin{array}{l}\text { Give a brief of the general election in the U.S.A taking the } 2016 \text { general election for } \\
\text { example. }\end{array}$ \\
\hline 13 & $\begin{array}{l}\text { Education in } \\
\text { the U.S.A. }\end{array}$ & $\begin{array}{l}\text { Watch the video Why Did you Choose Yale, and then tell the differences between } \\
\text { American and Chinese universities. }\end{array}$ \\
\hline 14 & $\begin{array}{l}\text { Social } \\
\text { Movements of } \\
\text { the 1960's }\end{array}$ & $\begin{array}{l}\text { Watch the movie The Mona Lisa smile first, and then summarize what you learn from it } \\
\text { about the 1960's? }\end{array}$ \\
\hline 15 & $\begin{array}{l}\text { Music in the } \\
\text { USA }\end{array}$ & $\begin{array}{l}\text { Try to introduce the following celebrities } \\
\text { King of Pop Music: Michael Joseph Jackson } \\
\text { The King of Rock’n’ Roll: Elvis Presley }\end{array}$ \\
\hline 16 & $\begin{array}{l}\text { A Brief of } \\
\text { Canada }\end{array}$ & $\begin{array}{l}\text { It's said there are } 2 \text { languages, } 2 \text { religions, } 2 \text { laws...2 sets of almost everything i } \\
\text { Canada. Try to explain the Canadian Identity by examining the coat of arm of Canada. }\end{array}$ \\
\hline
\end{tabular}

To complete the teaching assignment, students must take the following steps.

Step 1: before-class preparation. Students choosing the same task are required to collect the necessary information, discuss among themselves, co-design one PPT before the class meeting. Each is responsible for presenting one part of the PPT at class.

Step 2: in-class teaching. According to the teaching plan, students take turns to perform their teaching task in front of the whole class whenever the teacher thinks it necessary. Each student's performance is basically limited within 10 minutes. When one student finishes his/her job, other students will comment on the performance according to the scoring rubrics (table 2) first; then, the teacher gives his /her opinion, and grades the student's performance. 
Table 2 Scoring Rubrics

\begin{tabular}{|c|c|c|c|c|c|c|c|c|c|}
\hline \multirow[t]{2}{*}{ student } & \multirow{2}{*}{$\begin{array}{l}\text { Clarity, } \\
\text { accuracy and } \\
\text { completeness } \\
40 \%\end{array}$} & \multirow[t]{2}{*}{ Pronunciation $10 \%$} & \multirow{2}{*}{$\begin{array}{l}\text { Correctness } \\
\text { of word and } \\
\text { grammar } \\
10 \%\end{array}$} & \multicolumn{3}{|c|}{ means of expression 15\% } & \multirow{2}{*}{$\begin{array}{l}\text { Manner } \\
5 \%\end{array}$} & \multirow{2}{*}{$\begin{array}{l}\text { PPT } \\
20 \%\end{array}$} & \multirow[t]{2}{*}{ total } \\
\hline & & & & $\begin{array}{l}\text { Reading } \\
5 \%\end{array}$ & $\begin{array}{l}\text { Reciting } \\
10\end{array}$ & $\begin{array}{l}\text { Lecturing } \\
15\end{array}$ & & & \\
\hline
\end{tabular}

Step 3: after-class feedback. Having finished their jobs, students are required to write a summary of their teaching, fill in the relevant parts of the table (table 3), and QQ both the summary and the table to their teacher.

To motivate students to work hard for quality teaching, in addition to the above mentioned scoring rubrics, a model teaching will be set in advance by a student who is carefully chosen by the teacher, so other students will have a concrete and achievable goal. ${ }^{[8]}$

As step 3 shows students' performances are evaluated by their classmates first and then by their teacher, who comment on both the strong and weak points and offer suggestion for improvement. The student, having finished the teaching task, fills in the required parts of the following table (table 3), forwards it to the teacher, and gets timely feedback. This arrangement intends to help both the student and the teacher make timely remedial adjustment.

Table 3 Students' self-evaluation and teacher’s feedback

\begin{tabular}{|l|l|l|l|l|l|l|l|}
\hline \multirow{3}{*}{ student } & \multicolumn{2}{|l|}{ Students' self-evaluation } & \multicolumn{2}{c|}{ filled by students } & \multicolumn{2}{l|}{ filled by teachers } \\
\cline { 2 - 7 } & excellent & satisfactory & needs improving & problem & $\begin{array}{l}\text { way } \\
\text { improve }\end{array}$ & problem & suggestion \\
\hline
\end{tabular}

\section{Validity assessment}

Task-based teaching has been practiced for years among English majors of Institute of Foreign Languages, Shandong University of Technology. To test its validity, the author did some investigation among 121 English Majors of 2016 in aspects of language skill, culture competence, team spirit, independent study, etc. Due to the lack of accurate measure, questionnaire and interview were employed.

Student interviews were conducted at the end of the course in June, 2017. 15 interviewees were randomly picked out of the 121 English majors of 2016. Their responses were recorded by text and voice.

It's the first time for me to teach in front of a large audience. I was very nervous, excited... and afraid of making any mistakes...it IS as challenging and demanding as you told us. But it is a very good way to learn the English culture and the English language... (Student L)

It's tiresome to listen to the teacher's monologue all class long. I sometime, can't help dozing off. Listening to my classmates lecture is a different experience... It lends me a new angle to examine what we're studying. (Student Z)

I enjoy the carefree atmosphere, interaction with my classmates... Sometime I was imagining it was me who was teaching in the front, and competed against my classmates. I meant to do a better job. (Student C)

Spurred by the teacher, I was forced to collect materials I need, make PPT and work with my partners ... I found it was not as hard as I had expected to express myself in English in public. (Student W)

It's no easy job to be a good teacher. It took me almost 4 hours to prepare the 10-minute teaching. However, it is very worthwhile. (Student $\mathrm{J}$ )

To get a complete picture of students' feedback, 121 copies of questionnaire were sent out to 121 
English majors of 2016 around June, 2017, who were invited to offer responses to the following questions:

(1) How much do you like student presentation?

(2) In what degree did it help build up your cultural knowledge?

(3) In what degree did it help build up your English proficiency

(4) Did it facilitate independent study?

(5) Did it help cultivate team spirit?

(6) Did it help to build up confidence?

(7) Should it be spread in future teaching practice?

(8) Is there any problem with it?

(9) What do you like or dislike it most?

(10)What's your suggestion to improve it?

118 out of 121copies were collected, which were all valid. An analysis of the feedback revealed a very similar finding with that of the above-mentioned interviews: the overwhelming majority of the students like the practice very much. A few students say "I know it's good for me in many aspects, but the problem is I am too shy to speak in public."

Problems are also detected by students. (1) If a student is not well-prepared in advance, or if the English of a student is not good enough to make quality teaching, the limited time in class might be lavishly wasted. (2) Students sometime can't produce systemic teaching due to the 10-minute-time limit. (3)Some students speak too fast to be understood. (4) Some students want to watch their lectures.

Having discussed with fellow teachers and referred to students' suggestion, the author worked out the following ways to tackle the problems (1) Student-designed PPTs are subject to teacher's approval, and rehearsals are mandatory among group members before each class meeting. (2) The time limit can be lengthened to 15 or 20 minutes if necessary. (3) Students' teaching are videotaped and posted on QQ. (4) Students’ PPTs are posted on QQ after class.

\section{Conclusion}

The author has experimented with task-based teaching among sessions of English majors, finding the practice, if carefully planned, can naturally integrate cultural content into the FL curriculum. Students, output-driven, and score-driven, are motivated to employ their English knowledge and skills: listening, speaking, reading, writing in every step to complete the tasks to acquire the cultural knowledge. Meanwhile, each individual student gains, more or less, in ability to study independently and collaboratively, and to think creatively. All the above combined can help produce productive learners.

\section{References}

[1] Cammarata, Laurent. Foreign Language Teachers' Struggle to Learn Content-Based Instruction [J]. L2 Journal, 2010,2(1)

[2] Lambert, W. E., \& Tucker, G. R. The bilingual education of children: The St. Lambert experiment. Rowley [M]. MA: Newbury House. 1972

[3] Brinton, D. M., Snow, M. A., \& Wesche, M. Content-based second language instruction (2nd Ed.). Ann Arbor[M]. MI: The University of Michigan Press. 2003

[4] Chang Junyue, Zhao Xiuyan, Li Lili. Feasibility Exploration of Content Relying Teaching in English Majors' Lower Stage System[J]. Foreign Language and Foreign Language Teaching, 
2008.1

[4] Chang Junyue, Dong Hainan. An Empirical Study on the Content of English Majors Based on Teaching Contents [J]. Foreign Language and Foreign Language Teaching, 2008.5

[6] Clegg, John. Content-Based Second Language Instruction by Donna M. Brinton [J]. Issues in Applied Linguistics 1990(1) 